Journal of Environmental Impact Assessment, Vol. 22, No. 5(2013) pp.529 536

http://dx.doi.org/10.14249/eia.2013.22.5.529

\title{
연구노트
}

\section{Blue Sky Project and Impact Assessment \\ - Examples of Urban Air Quality Management of Agenda 21 in Indonesia -}

\section{Sang-Don Lee}

Department of Environmental Science and Engineering, College of Engineering, Ewha Womans University

(Manuscript received 20 August 2012; accepted 12 September 2013)

\author{
푸른하늘과 영향평가 \\ - 인도네시아 아젠다21 도심 대기질 전략의 사례를 통하여 - \\ 이상 돈 \\ 이화여자대학교 환경공학과 \\ (2013년 8월 20일 접수, 2013년 9월 12일 승인)
}

\begin{abstract}
인도네시아 정부의 아젠다21은 지속가능한 환경을 유지하기 위한 노력을 지원하는 정부-기업-시 민 3 자 시스템이다. 국가의 경제개발과 환경적 조화를 이루는 것이 중요하다는 것을 보여주는 국가의 의지이다. 인도네시아는 대기질 관리가 매우 중요하며 도시대기질관리전략은 1992년 대도시환경개 성프로그램으로 채택되었다. 도시대기질프로그램(UAQP)는 '푸른하늘'을 목표로 하며 UAQP는 각 전략단계에 대기오염의 원인을 찾아내고 실행전략으로 유도한다. 아젠다21을 대기질 유지를 위해 수 행하는 좋은 예이며 푸른하늘전략은 지속가능한 환경을 유지하기 위한 중요한 프로그램이다.

주요어 : Blue sky program, Agenda 21, Local government, Indonesia, Air Quality Control
\end{abstract}

\section{Introduction}

As a country with rich environmental and natural resources, Indonesia actively engages in maintaining the quality of environment. It has been almost 17 years since Indonesia stated its commitment about sustainable development and signed Rio Declaration on Environment and Development on June 5, 1992 (President of
Indonesia, 1994).

Indonesian government introduced Agenda 21 as the action plan to execute sustainable development. It was at the end of 1996, and then followed by the establishment of Commission on Sustainable Development (CSD) in 1997, under the Ministry of Environment as the key national coordination. Then, together with Ministry of Forestry, they cooperated to create sustainable

Corresponding Author: Sang-Don Lee, Department of Environmental Science and Engineering, College of Engineering, Ewha Womans University, Seoul 120-750, KOREA Tel: +82-2-3277-3545 Fax: +82-2-3277-3275 E-mail: 1sd@ewha.ac.kr 
development, especially in preserving the environment (Department of Economic and Social Affairs, 1999). Data from the United Nations Divisions for Sustainable Development showed that in 2004 Ministry of Settlements and Regional Infrastructure was added to the CSD membership in Indonesia.

Originally, national Agenda 21 of Indonesia consists of four areas: community services, waste management, land resource management, and natural resource management. Furthermore, the national Agenda 21 is expanded into five sectors: energy, forestry, tourism, settlement, and mining. According to the report from National Development Planning Agency, only Jakarta has its own local Agenda 21. However, implementation has been made in local levels based on national Agenda 21.

At governmental level, Jakarta's Agenda 21 was stated in Local Strategic Assessment Plan 2002-2007 issued by Jakarta Local Development Planning Agency. The policies related to Agenda 21 are:

1. To maintain natural resources, preserve supporting capacity, conservation and rehabilitation efforts, also encourage efficiency usage and using environment-friendly technology.

2. To balance the issues of environment and socio-economy in the context of sustainable development.

3. To create a clean city being free from pollution by implementing effective technology.

\section{Urban Air Quality Control Program in Indonesia}

Indonesia's development highly depends on fossil fuels, especially oil. The annual consump- tion of crude oil from 1996 to 2005 was in the rage of 355 to 420 million barrels (Santosa et al., 2008). Other sources of energy were much less consumed than oil. One of the most outstanding commitments of Jakarta government was the launching of Local Regulation about Smoking Prohibition Areas (Government of Jakarta, 2005), with the objectives of decreasing illness and/or death rate by doing healthy behaviors; increasing work productivity; creating free-from-smoke, clean and healthy air quality; decrease smoker numbers and prevent new smokers; create healthy generations (Government of Jakarta, 2005; Jakarta Local Development Agency, 2007). Although the implementation is still not satisfying and the law enforcement of this regulation is low, but government hopes that other provinces will follow Jakarta's effort to create clean air and improve air quality in the city. Ministry of Environment introduced a special program for improving air quality called "Langit Biru" (Blue Sky) program for city government. In order to attract active participation from the public in preserving the environment, the government of Indonesia since 1981 also awarded a specific award called "Kalpataru" (Ministry of Environment, 2008a, b).

There were eight cities awarded "Langit Biru" by the Ministry of Environment in 2007: Bandung, Denpasar, Jakarta, Makassar, Medan, Semarang, Surabaya, and Yogyakarta (Ministry of Environment, 2007) (Fig. 1).

Every year, Bandung government holds air quality assessment (roadside and ambient) to maintain its pollution level. Free emission test is also provided. In 2006, the government conducted pilot project on using biofuel at Damri, a bus company. It also conducted machine performance 


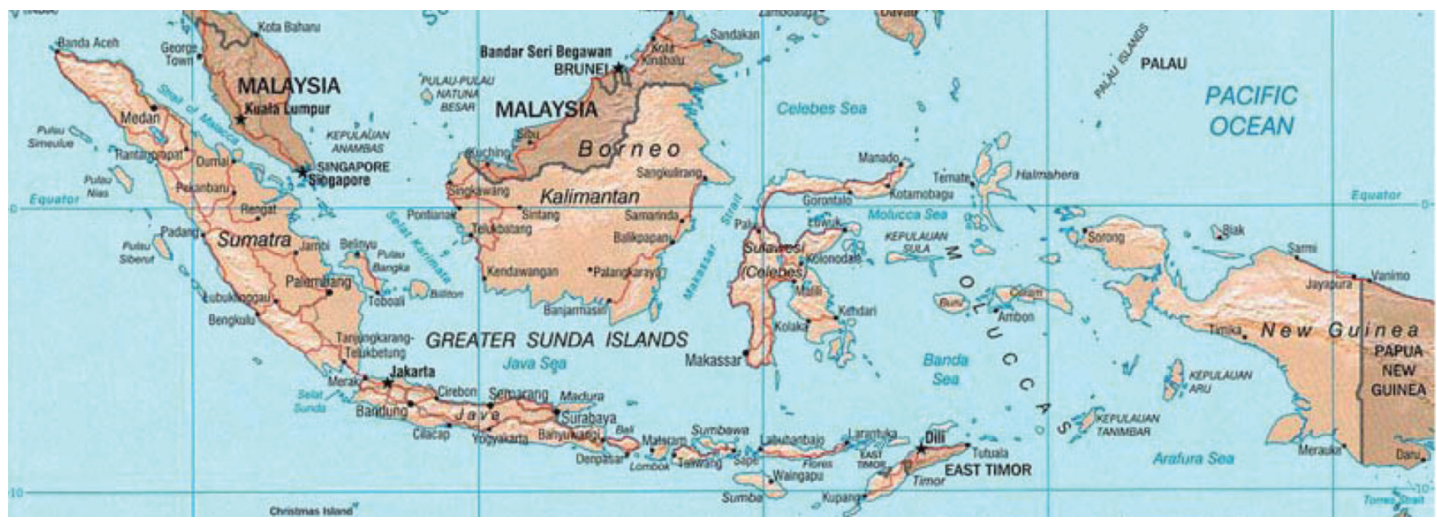

Fig. 1. Eight cities awarded Blue Sky in 2007 in islands of Indonesia

analysis based on emission test. Bandung also builds partnership with National Development Planning Agency in creating action plan for UAQI (Urban Air Quality Indonesia) program.

Denpasar also has roadside air quality measuring each year, but since 2004 it didn't conduct ambient air quality measuring. Another effort to reduce air pollution was aimed by conducting Sarbagita (Denpasar, Badung, Gianyar, Tabanan) traffic analysis program. Seclusion Day celebrated by Hindu people, who are the biggest population in Bali, also contributes to reduce air pollution once in a year. New breakthrough was made by Bali government by conducting Car-free Day every Friday for all government employees.

Jakarta has both ambient and roadside air quality monitoring annually. Since 2007, the measurement process was conducted automatically by mobile roadside facilities. Jakarta had implemented emission inventory program since 1992, but it wasn't conducted regularly. Other activity to support the improvement of air quality was community participation building through Mitra Emisi Bersih (Clean Emission Partnership) which holds annual emission test, cooperates with local and overseas organization, advocacy in environmental policies, etc. Since 2008, Car-free
Day is conducted in Jakarta every Saturday or Sunday, but for now it's just limited to main streets.

Makassar, same with Denpasar, has implemented roadside air quality monitoring. It also has annual emission test. In the other hand, Medan and Semarang haven't implemented air quality monitoring yet, but they have emission test programs and are having cooperation with National Development Planning Agency in creating action plan for UAQI program. A center for emission test is being established in Medan, and a study about mass transportation is being held in Semarang.

Surabaya as the 3rd largest city in Indonesia has ambient air quality measuring, but hasn't implemented roadside air quality measuring. It has quarterly-based emission test, partnership for UAQI, and a forum consists of government and people called FURBES (Forum Udara Bersih Kota Surabaya or Surabaya Clean Air City Forum) of which activities are concentrated in improving air quality in Surabaya. Yogyakarta, in contrast to Surabaya, for now is only implementing roadside air quality measuring. It also has free emission test for local people. A bicycle community was formed by Yogyakarta people, and there is a club 
Table 1. Indicators of air quality measuring in seven cities excluding Jakarta

\begin{tabular}{c|c|c|c|c|c|c|c}
\hline \multirow{2}{*}{ Pollutants } & \multicolumn{7}{c}{ City Score $\left(\mathrm{ug} / \mathrm{Nm}^{3}\right)$} \\
\cline { 2 - 9 } & Bandung & Denpasar & Makassar & Medan & Semarang & Surabaya & Yogyakarta \\
\hline Carbon monoxide $(\mathrm{CO})$ & $5,750.00$ & 414.23 & $2,509.37$ & $8,185.57$ & $6,659.55$ & $13,657.64$ & $3,889.83$ \\
\hline Nitrogen dioxide $\left(\mathrm{NO}_{2}\right)$ & 30.76 & 24.58 & 51.02 & 105.92 & 20.24 & 12.09 & 10.12 \\
\hline Hydrocarbon $(\mathrm{HC})$ & 142.58 & 52.92 & 54.81 & 84.34 & 159.30 & 0.00 & 216.67 \\
\hline \hline
\end{tabular}

source: Ministry of Environment, 2007

Table 2. Indicators of air quality measuring in five areas of Jakarta

\begin{tabular}{c|c|c|c|c|c}
\hline \hline \multirow{2}{*}{ Pollutants } & \multicolumn{5}{|c}{ City Score $\left(\mathrm{ug} / \mathrm{Nm}^{3}\right)$} \\
\cline { 2 - 6 } & North Jakarta & South Jakarta & West Jakarta & East Jakarta & Central Jakarta \\
\hline Carbon monoxide $(\mathrm{CO})$ & $5,750.00$ & 414.23 & $2,509.37$ & $8,185.57$ & $6,659.55$ \\
\hline Nitrogen dioxide $\left(\mathrm{NO}_{2}\right)$ & 30.76 & 24.58 & 51.02 & 105.92 & 20.24 \\
\hline Hydrocarbon $(\mathrm{HC})$ & 142.58 & 52.92 & 54.81 & 84.34 & 159.30 \\
\hline \hline
\end{tabular}

source: Ministry of Environment, 2007

called YCAC (Youth Clean Air Club) established by senior high school students who are committed to take care of their vehicles to reduce emission. Yogyakarta is known as the city with large use of motorcycles in Indonesia.

There are 3 indicators of air quality in Indonesia: Carbon monoxide (CO), Nitrogen dioxide (NO2), and Hydrocarbon (HC) based on Ministry of Environment (2007). The emission level of each air pollution is listed in Table 1, and Syrabaya is the highest for CO, and Medan is the highest for NO2, and Yogyakarta is the highest for HC. Also the air quality level around Jakarta is relatively high in $\mathrm{CO}$ for east Jakarta, and HC for Central Jakarta (Table 2).

Due to high in air pollution level the local Agenda 21 set up for strategy and action plan for Urban Air Quality Improvement Action plan (Table 3). According to Action plan there are three parts for air quality improvement: Analysis - Strategic Intervention? Action Plan.

For population growth in urban areas we should deconcentrate city development so that source of air pollution should be dissipated, and for landscape imbalance transportation system and rationalize urban land use pattern should be

Table 3. Strategy and Action Plan for Urban Air Quality Improvement

\begin{tabular}{|c|c|c|}
\hline $\begin{array}{c}\text { Analysis } \\
\text { (Causes of Air Pollutions) }\end{array}$ & $\begin{array}{c}\text { Strategic Intervention } \\
\text { (Prevention of Air Pollutions) }\end{array}$ & $\begin{array}{c}\text { Action Plan } \\
\text { (to Prevent Air Pollutions) }\end{array}$ \\
\hline $\begin{array}{l}\text { Population growth and high } \\
\text { urbanization growth }\end{array}$ & $\begin{array}{l}\text { Deconcentrate and planned } \\
\text { city development }\end{array}$ & - Deconcentrate and planned city development \\
\hline Imbalance in landscaping & $\begin{array}{l}\text { Integrate transportation system } \\
\text { and rationalize urban land use }\end{array}$ & $\begin{array}{l}\text { - Arrange recommendations for urban planning with zoning system } \\
\text { - Arrange regulations of providing transportation system in zone } \\
\text { development } \\
\text { - Provide green areas around cities which are integrated in national, } \\
\text { provincial, and district planning } \\
\text { - Provide and develop city parks as green open areas for recreation and } \\
\text { sports } \\
\text { - Develop clean air zones inside cities, especially in sensitive areas like } \\
\text { universities, hospitals, shopping centers and sport fields } \\
\text { - Arrange industrial activities which cause traffic near sea ports, airports, } \\
\text { train stations and highway, but in safe distance from sensitive zones like } \\
\text { housing and schools }\end{array}$ \\
\hline
\end{tabular}


Table 3. Continued

\begin{tabular}{|c|c|c|}
\hline $\begin{array}{c}\text { Analysis } \\
\text { (Causes of Air Pollutions) }\end{array}$ & $\begin{array}{c}\text { Strategic Intervention } \\
\text { (Prevention of Air Pollutions) }\end{array}$ & $\begin{array}{c}\text { Action Plan } \\
\text { (to Prevent Air Pollutions) }\end{array}$ \\
\hline $\begin{array}{l}\text { Dependence to oil as } \\
\text { energy sources }\end{array}$ & $\begin{array}{l}\text { Promote energy conservation } \\
\text { and utilization of alternative } \\
\text { energy }\end{array}$ & $\begin{array}{l}\text { - Arrange regulations about alternative fuel } \\
\text { - Promote infrastructure development to increase utilization of gas fuel } \\
\text { - Arrange regulation of standardization of usage and utilization of coal in } \\
\text { industry } \\
\text { - Arrange incentive mechanism for conservation tools and energy } \\
\text { diversification and implementation } \\
\text { - Conduct researches about increasing productivity of raw materials to } \\
\text { produce biofuel } \\
\text { - Conduct researches to optimize manufacturing process of biofuel } \\
\text { - Conduct pilot projects of planting raw materials to produce biofuel } \\
\text { - Provide incentive to utilize alternative energy } \\
\text { - Replace fuels of government's operational vehicles with alternative fuels }\end{array}$ \\
\hline $\begin{array}{l}\text { Lack of community } \\
\text { awareness }\end{array}$ & $\begin{array}{l}\text { Conduct campaign to increase } \\
\text { community awareness }\end{array}$ & $\begin{array}{l}\text { - Develop information centers and the equipments } \\
\text { - Develop database system about air pollutions } \\
\text { - Improve and promote website about air pollutions in Ministry of } \\
\text { Environment's website or related institutions } \\
\text { - Improve quality of human resources in information field } \\
\text { - Arrange strategies and campaign plans to increase knowledge and } \\
\text { attention from public and government employees } \\
\text { - Implement campaign to increase community awareness based on work } \\
\text { planning } \\
\text { - Enact policies about air pollution topics in curriculum for elementary } \\
\text { school, junior high school, and high school in big cities } \\
\text { - Utilize government's communication media } \\
\text { - Evaluate the execution of public campaign }\end{array}$ \\
\hline Poor fuel quality & Increase fuel quality & $\begin{array}{l}\text { - Determine fuel specification in Indonesia } \\
\text { - Determine fuel quality road map for medium and long-terms } \\
\text { - Conduct fuel quality testing routinely }\end{array}$ \\
\hline Bad emission of vehicles & $\begin{array}{l}\text { Implement standard and } \\
\text { emission threshold level }\end{array}$ & $\begin{array}{l}\text { - Provide emission testing facilities for new type of vehicles of motorcycle } \\
\text { and vehicle with weight }>3.50 \text { tons } \\
\text { - Conduct type testing based on standard of EURO II } \\
\text { - Determine road map for emission standards of new type vehicles } \\
\text { - Revitalize system of vehicle operation testing } \\
\text { - Broaden the compulsory emission testing as a part of vehicle operation } \\
\text { testing for private vehicles } \\
\text { - Revise emission's threshold limit value for vehicles that has been } \\
\text { operating } \\
\text { - Arrange and implement incentive program for emission system control } \\
\text { for vehicles that has been operating } \\
\text { - Give incentives to low-emission, very-low-emission, and zero-emission } \\
\text { vehicles }\end{array}$ \\
\hline $\begin{array}{l}\text { Poor urban transportation } \\
\text { system and traffic } \\
\text { management }\end{array}$ & $\begin{array}{l}\text { Implement effective } \\
\text { transportation and traffic } \\
\text { management }\end{array}$ & $\begin{array}{l}\text { - Develop master plan of transportation in metropolitans and big cities } \\
\text { - Develop rapid bus transportation in metropolitans and big cities } \\
\text { - Revitalize facilities and infrastructure of railway-based mass rapid } \\
\text { transportation } \\
\text { - Arrange minimum service standard for public transportation } \\
\text { - Develop transit facility for intermodal transportation } \\
\text { - Arrange law basis for implementing road pricing system } \\
\text { - Develop facilities and promote usage of non-motorized transportation } \\
\text { - Promote usage of railway and water for cargo transporting } \\
\text { - Promote collective using of vehicles } \\
\text { - Alternate cargo transporting which passes the center of the cities } \\
\text { - Arrange criteria for sustainable transportation management } \\
\text { - Conduct city assessment based on criteria of sustainable transportation }\end{array}$ \\
\hline
\end{tabular}


Table 3. Continued

\begin{tabular}{|c|c|c|}
\hline $\begin{array}{c}\text { Analysis } \\
\text { (Causes of Air Pollutions) }\end{array}$ & $\begin{array}{c}\text { Strategic Intervention } \\
\text { (Prevention of Air Pollutions) }\end{array}$ & $\begin{array}{c}\text { Action Plan } \\
\text { (to Prevent Air Pollutions) }\end{array}$ \\
\hline $\begin{array}{l}\text { Uncontrolled industry } \\
\text { emission }\end{array}$ & $\begin{array}{l}\text { Implement adherence of } \\
\text { emission standard for industry }\end{array}$ & $\begin{array}{l}\text { - Revise Ministry of Environment's decree about emission standard for } \\
\text { industry } \\
\text { - Revise regulations which are against environmental standard operation } \\
\text { procedure } \\
\text { - Monitor the implementation of environment management with EIA, } \\
\text { SOP through provincial governments } \\
\text { - Give incentives to motivate industries which lower air emissions }\end{array}$ \\
\hline $\begin{array}{l}\text { Other } \\
\text { not be }\end{array}$ & $\begin{array}{l}\text { Control pollution from other } \\
\text { sources }\end{array}$ & - Arrange regulations of fugitive emission in fuel charging \\
\hline $\begin{array}{l}\text { Parameters of air } \\
\text { pollutions }\end{array}$ & $\begin{array}{l}\text { Integrated monitoring of } \\
\text { ambient air quality }\end{array}$ & $\begin{array}{l}\text { - Revise parameters of ambient air standards, threshold limit values based } \\
\text { on researches } \\
\text { - Monitor ambient air quality using Air Quality Monitoring System in } \\
\text { metropolitans and big cities }\end{array}$ \\
\hline $\begin{array}{l}\text { Availability of air quality } \\
\text { data }\end{array}$ & $\begin{array}{l}\text { Strengthen air quality } \\
\text { monitoring system (AQMS) } \\
\text { of national and local }\end{array}$ & $\begin{array}{l}\text { - Provide and improve AQMS for Yogyakarta, Jakarta, and other cities } \\
\text { which have or don't have AQMS? } \\
\text { - Develop air quality monitoring methods with passive and active } \\
\text { samplers and conduct pilot projects } \\
\text { - Develop alternative air quality monitoring methods } \\
\text { - Develop network of integrated air quality monitoring }\end{array}$ \\
\hline $\begin{array}{l}\text { Limit } \\
\text { inven }\end{array}$ & $\begin{array}{l}\text { Arrange sustainable database } \\
\text { of emission inventory }\end{array}$ & $\begin{array}{l}\text { - Conduct pilot projects of emission inventory } \\
\text { - Arrange information system and database of emission results }\end{array}$ \\
\hline Undeveloped modeling & $\begin{array}{l}\text { Develop air quality prediction } \\
\text { methods }\end{array}$ & $\begin{array}{l}\text { - Develop air quality prediction methods and the impacts of } u \\
\text { quality management policies }\end{array}$ \\
\hline $\begin{array}{l}\text { Irregular dis } \\
\text { air quality ir }\end{array}$ & $\begin{array}{l}\text { Disseminate air quality } \\
\text { information regularly }\end{array}$ & $\begin{array}{l}\text { - Provide daily information about air pollutions in mass media } \\
\text { - Arrange procedure to access information about air quality }\end{array}$ \\
\hline $\begin{array}{l}\text { Impacts of air pollutions to } \\
\text { health }\end{array}$ & $\begin{array}{l}\text { Comprehensive monitoring and } \\
\text { control for air pollution health } \\
\text { impacts }\end{array}$ & $\begin{array}{l}\text { - Conduct comprehensive surveillances about health risk factors } \\
\text { - Conduct surveillances about disease and death related to respiration, } \\
\text { pneumonia and asthma } \\
\text { - Conduct surveillances about disease and death related to cardiovascular, } \\
\text { cancers and other chronic diseases } \\
\text { - Conduct studies and researches on health impacts and management of } \\
\text { specific air pollutants } \\
\text { - Review the regulations about health impacts of air pollutions and revise } \\
\text { when necessary } \\
\text { - Arrange technical guidelines to control health impacts of air pollutions } \\
\text { - Improve skills of Technical Office of Environmental Health and Disease } \\
\text { Control to monitor and review aspects of air pollutions and } \\
\text { environmental health } \\
\text { - Conduct prevention through healthy life promotion and environmental } \\
\text { health promotion }\end{array}$ \\
\hline $\begin{array}{l}\text { Impacts of air pollutions } \\
\text { to plants }\end{array}$ & poinutions & - Conduct researches about air pollutions' impacts to plants \\
\hline $\begin{array}{l}\text { Impacts of air pollutions } \\
\text { to buildings }\end{array}$ & $\begin{array}{l}\text { Control of air pollutions' } \\
\text { impacts to buildings }\end{array}$ & - Maintain buildings and prevent damage by air pollutions \\
\hline $\begin{array}{l}\text { Economic consequences } \\
\text { of air pollutions }\end{array}$ & $\begin{array}{l}\text { Control of air pollutions' } \\
\text { impacts to economy }\end{array}$ & $\begin{array}{l}\text { - Conduct researches about air pollutions' impacts to economy and } \\
\text { disseminate the results }\end{array}$ \\
\hline Insufficient capacity & $\begin{array}{l}\text { Create intersectoral } \\
\text { coordination team responsible } \\
\text { for urban air quality } \\
\text { improvement }\end{array}$ & $\begin{array}{l}\text { - Arrange mechanism for coordination and coordination team to } \\
\text { implement strategies and national action plan } \\
\text { - Analyze human resources' needs and capacity }\end{array}$ \\
\hline
\end{tabular}


Table 3. Continued

\begin{tabular}{l|l|l}
\hline \hline $\begin{array}{c}\text { Analysis } \\
\text { (Causes of Air Pollutions) }\end{array}$ & $\begin{array}{c}\text { Strategic Intervention } \\
\text { (Prevention of Air Pollutions) }\end{array}$ & \multicolumn{1}{c}{$\begin{array}{c}\text { Action Plan } \\
\text { (to Prevent Air Pollutions) }\end{array}$} \\
\hline $\begin{array}{l}\text { Disintegrated policies and } \\
\text { regulations about air } \\
\text { quality management }\end{array}$ & $\begin{array}{l}\text { Synchronize regulations and } \\
\text { develop technical guidelines }\end{array}$ & $\begin{array}{l}\text { - Revise and synchronize acts and implementations related to urban air } \\
\text { quality improvement } \\
\text { - Develop technical guidelines to improve air quality } \\
\text { - Arrange academic draft of Clean Air Act }\end{array}$ \\
\hline $\begin{array}{l}\text { Weak law enforcement } \\
\text { improving air quality }\end{array}$ & Strengthen law enforcement & $\begin{array}{l}\text { - Conduct vehicle checking with focus on emission } \\
\text { - Provide emission testing facilities which are used while checking } \\
\text { vehicles }\end{array}$ \\
\hline Insufficient funding & Mobilize funding sources & $\begin{array}{l}\text { - Conduct random checking to industries } \\
\text { - Establish information and communication center } \\
\text { - Conduct training for local staffs }\end{array}$ \\
\hline \hline
\end{tabular}

source: National Development Planning Agency, 2006

integrated with zoning system by providing green areas and developing parks (National Development Planning Agency, 2006). Energy should be more diversified to encourage energy conservation with alternative energy. Increase fuel quality is an important issue to determine fuel quality road map for medium and long-term measures and also conduct fuel quality testing. Poor urban transportation system and traffic management should be changed by implementation of effective transportation and traffic management for metropolitans and big cities. Impacts of air pollutions to plants and buildings should be assessed for plant experimentation and building damage monitoring. Insufficient capacity should be analyzed for human resources' needs and capacity. The law enforcement should be strengthened to provide emission testing facilitated and conduct random checking to industries.

\section{Conclusions}

Indonesian government has realized the importance of maintaining environment for the future of the country. Several efforts have been done to manage air quality level. In recognition of the growing severity of air pollution and the weak capacity in managing air quality the Urban Air Quality Management Strategy (URBAIR) was adopted in 1992 as part of Metropolitan Environmental Improvement Program (Development Planning Agency, 2006). For a better air quality management one should include (Santosa et al., 2008):

- Development of more accurate and precise methods of determination

- Determination of and monitoring air pollutants

- Development of more reliable inventories of air pollution emissions

- Taking a more integrative approach to determining air pollutants

- Better inspection and source identification of emissions

- Estimation and quantification of emission sources

- Taking a more strategic approach to managing air quality to include all aspects of the 
problem

- Harmonization of air quality standards across Indonesia

- Adopting more stringent vehicle emission standards

- Using cleaner fuels for motor vehicles, industry and power plants

- Stricter enforcement of legislation and more stringent standards for air quality

The capability of the Indonesian authorities to manage the urban air quality is still very limited and the portion of the budget allocated to the improvement of urban air quality is still remarkable low, typically lower than $1 \%$ of the total. This is why people should make efforts to enhance the capability of the urban air quality which cannot be handled by the environmental authorities in Indonesia's cities themselves.

Acknowledgements: This study was financially supported by KEITI (403-112-005), LTER (1600016001-2) and MEST(2014). Author wishes to thank Ms. Oktavia Ratnasari and Sry Wahyuni Warastuti who work for the Indonesian government of Environment.

\section{References}

Department of Economic and Social Affairs, 1999, Assessment of Progress in the Implementation of Agenda 21 at the National Level: Table of Key Coordination Mechanisms and Actions.

Government of Jakarta, 2005, Jakarta Capital City Law Number 75 Year 2005 about Smoking Prohibited Areas.

Jakarta Local Development Agency, 2007, Local Strategic Planning 2002-2007 Chapter XI: Natural Resources and Environment.

Ministry of Environment, 2007, Profile of Blue Sky Cities.

Ministry of Environment, 2008a, Environment Savior: Pekraman Buahan Village.

Ministry of Environment, 2008b, Environment Pioneer: Cukup Rudiyanto.

National Development Planning Agency, 2006, Urban Air Quality Improvement, National Strategy and Action Plan.

President of Indonesia, 1994, Republic of Indonesia Act Number 5 Year 1994 about the Ratification of United Nations Convention on Biological Diversity.

Santosa, S.J., Okuda, T., and Tanaka, S., 2008, Air pollution and urban air quality management in Indonesia, Clean 36, 466475. 